\title{
ON THE COVER
}

\section{Our Haven in Antibes by John B. Martin}

A woman stands by the side of a road hitching a ride, placard held aloft. (This cartoon is from some years agoback when such a sight might be imaginable, rather than high risk.) Her destination? "Away."

For those of us in northern climes, this time of year may not feel quite as desperate as it will a month or so from now, during "cabin fever" season. And yet even now, the idea of spending time in warmth and sunlight, if only for a while, holds great appeal.

John B. Martin, whose watercolor painting of an interior in the south of France provides this month's cover art, has a strong affection for France. He also has the great good fortune to have a friend with a pied à terre in Antibes, a small port city on the French Riviera. Martin and his wife Linda have stayed in this apartment annually for a number of years-and their friend even comes to visit while they are there. That he thinks of it as a "haven" is a lovely double entendre, whether intended or not, because that word refers to not only a refuge but also a port or harbor.

Martin grew up in Chicago, the eldest of two. As noted in a previous essay on this artist (see his cover image of Le Pont Neuf and accompanying essay in the February-March 2019 issue of the American Psychologist), his father began teaching him to draw before he entered kindergarten. Although Martin won prizes and obtained scholarships in art, he majored in psychology in college and went on to study psychology in graduate school, obtaining a master's from Harvard in the late 1950s and a PhD from the University of Chicago in 1963.

While Martin was at Harvard, one of his mentors was Henry A. Murray, the developer of the Thematic Apperception Test, a classic in projective testing. Martin comments that Murray encouraged his interest in painting and drawing. Murray was one of Martin's favorite people: Martin confided in him with some struggles he was experiencing in his personal life and recalls that Murray "helped me muddle through that."

One of the early psychologists in independent practice, Martin specialized in group and couples therapy. At his office near Evanston, Illinois, he says that he "focused on relationships and all their vicissitudes and nuances."

At his wife's encouragement, Martin began taking watercolor classes at the Evanston Art Center. His teacher ultimately created her own studio, and Martin has been working with her in the 30 years since. He still attends every Monday morning, describing his experience as "like an advanced salon" in which a small group of artists regularly critique each other's work. "It's been an enormously rewarding affiliation," comments this 90-year-old.

Martin has enjoyed travel for decades. Having spent time as an undergraduate student in France on a Fulbright scholarship, he is drawn to that country in particular. He is especially intrigued by the light and shadow of the coastal area, describing it as influenced by the ocean and its "accoutrements." Often painting exteriors and landscapes, he notes in particular the architecture along the coast, the sun-washed pastel colors of the buildings, at times the religious structures as well. This offers settings that are "given to wonderful variegation in color and shadows."

This painting of the living room of their "haven" is filled with light; it is this combination of light and shadow that drew Martin to this scene. Light streams in from the balcony, through the open French doors, creating a lattice work pattern on the tile floor and deeper purple shadow farther into the interior. Martin notes:

In most of my compositions, what matters as much as anything are some of the contrasts-light and shade and complementary colors What intrigued me about [this living room] in the first place was the way in which the sunshine streamed through the balcony onto the floor, brightening up the fireplace and creating wonderful shadows that seemed to bounce off that chair.

One recognizes that this is a very real place, with its Art Deco chair and wall sconce and its mammoth-albeit nonworking-fireplace. The curves of the chair are echoed in the fireplace and the bright orange afghan draped on a bench. They offer a contrast to the linearity of doors, tiles, and squared-off rug, echoed in the picture on the mantel and books on the table. Plum and green, the softening yellow, and the spot of orange engage the eye, whereas the centered chair and open door bring the observer in through the room and toward the open air outside.

Light, shadow, and warmth: This painting invites us to reflect on those aspects of our lives that are welcoming whether at home or away.

Kate F. Hays Art Co-Editor 